\title{
UNITED NATIONS ACTIVITIES
}

UN

- Criminal Law and the Protection of the Environment (G. Loibl and M. Reiterer)

UNCLOS

- International Tribunal Starts Work

UN-CSD

- Preparations for UNGASS

- Financing Biodiversity Conservation (R. Lake)

- The Biodiversity Convention Negotiation Process and Some Comments on the Outcome (V. Koester)

- Erratum

The Biodiversity Convention Negotiation Process and some Comments on the Outcome (V. Koester)

UN/ECE

- First Meeting of the Parties to the ECE Water Convention

\section{UNEP}

- 19th Session Governing Council

- Review of Montevideo Programme

- High-Level Meeting of Ministers and Officials

UNFCCC

- Meeting of the Subsidiary Bodies (M. Ehrmann)

- Spring in Climate Negotiations? (M. Ehrmann/S. Oberthür)

\section{UN/GA}

- 51th Session
- Convention on International Watercourses

UN/GASS

$400 \quad-\quad$ 19th Special Session

388

Biodiversity Convention

- The Next Rosy Periwinkle Won't Be Free: Emerging Legislative Frameworks to Implement Article 15 of the Convention on Biological Diversity (L. Glowka)

- Third Session of the Conference of the Parties

CSD

175

- Intergovernmental Forum on Forests: First Session

ECOSOC

- Decision on NGOs

ICJ

- Hungary/Slovakia: Judgement on Gabcikovo

IMO

- MARPOL: New Annex for Convention

INCDesertification

- Desertification Convention: COP-1

- Tenth Session: Beginning of Implementation

- Decisions on Illegal CFC Trade and Multilateral Fund

- Open-Ended Working Group of the Parties (D.M. Miller)

192 - Montreal Protocol: 10 Years after (S. Oberthür)

\section{OTHER INTERNATIONAL DEVELOPMENTS}

Financial Resources for Biodiversity Conservation The Impact of Tourism and Air Transport on the Small Island Developing States

(R.I.R. Abeyratne)

Sustainable Development in the Oceans

(E. Mann-Borgese)

Les mécanismes de contrôle de la mise en œuvre et du respect de la Convention de Bâle (M.-T. Perez Martin)

Elizabeth Haub Prize 1996

The Rise and Fall of the Patagonian Toothfish Food for Thought (G. Lugten)
9 The Alpine Convention - An Update (W. Burhenne)

198 The convention and Switzerland International Transfer of Environmentally Sour Stumbling Block (G. Verhoosel)

209 XI World Forestry Congress

210 APCEL

- Teaching Environmental Law: Trends in the

401 
Indigenous People

- Emerging New Legal Standards for Comprehensive Rights

IUCN

(J. Sutherland, D. Craig, D. Posey)

- Changes in Governance - Structure and Policy - 30 (E. A. Michos-Ederer)

\section{UNEP/IUCN}

- Joint Action Planned

- Committee on Trade and the Environment 33

- Singapore Meeting

(R. Tarasofsky)

\section{REGIONAL AFFAIRS}

\section{EP}

- Monitoring MEAs

Europe

- The New Direction of Water Protection Policy (U. Schleicher)

- Improved Environmental Protection Through an Expanded Concept of Human Rights?

EU (A. Rest)

- Directive on Air Quality
- Industrial Pollution Directive

- The Europeanisation of Domestic Policy:

- The Development of EC Environmental Policy 48 (C. Knill)

- Environment Council Decisions

- Environment Chapter in Maastricht II

- Environmental Agreements

- Application of Community Law

EU/ACP

- Climate Change and Small Island States

\section{NATIONAL AFFAIRS}

\section{Argentina}

- Developments in Environmental Law (Anibal Jose Falbo)

\section{Cameroon}

- Overcoming the Legal and Institutional Challenges to Implementing Cameroon's National Environmental Management Plan (C. Manga Fombad)

\section{Canada}

- Changes to Environment Regulations

France

- Clean Air Act Approved

- La loi du 30 décembre 1996 sur l'air et l'utilisation rationelle de l'énergie (J.-Y. Faberon)
Germany

- Challenge to Waste Law

- La protection conventionelle des espaces naturels

(E. Rehbinder)

- International Environmental Law in German Courts (A. Rest)

Ireland

- Government Backs Law Suit on Sellafield

- Natural Resource Damages -

112 A Swiss Law Perspective

USA

$$
\text { (H. R. Trüeb) }
$$

- Stricter Control on Air Emissions?

\section{SELECTED DOCUMENTS}

UN

- Convention on the Law of the Non-navigational Uses of International Watercourses

UN/CSD

- Decisions of the Fifth Session - Modalities for the full and comprehensive review of the Barbados Programme of Action adopted by the Global Conference on Small Island Developing States, 1994 -

UN/ECE

- The Helsinki Declaration - as adopted by the Meeting of the Parties to the Convention on the Protection and Use of Transboundary
Watercourses and International Lakes at Helsinki (Finland) on 4 July 1997 -

UN/GA: Resolutions

- Observer Status for the International Seabed Authority in the General Assembly

- Observer Status for the International Tribunal for the Law of the Sea in the General Assembly 112

- Cooperation between the United Nations and the Inter-Parliamentary Union

- Report of the International Atomic Energy Agency

- Zone of peace and cooperation of the South Atlantic 
- Law of the Sea

- Agreement for the implementation of the provisions of the United Nations Convention on the Law of the Sea of 10 December 1982 relating to the Conservation and Management of Straddling Fish Stocks and Highly Migratory Fish Stocks

- Large-scale pelagic drift-net fishing; unauthorised fishing in zones of national jurisdiction; and fisheries by-catch and discards 116

- Implementation of the Declaration of the Indian Ocean as a Zone of Peace

- Question of Antarctica

- International Decade of the World's Indigenous People

- Declaration on International Cooperation in the Exploration and Use of Outer Space for the Benefit and in the Interest of All States, Taking into Particular Account the Needs of Developing Countries

- Annex (of above)

- International cooperation in the peaceful uses of outer space

- United Nations Decade of International Law

- Annex: Programme for the activities for the final term (1997-1999) of the United

Nations Decade of International Law

- Electronic treaties database

- 1999 Action Dedicated to the Centennial of the First International Peace Conference and to the Closing of the United Nations Decade of International Law

- Report of the International Law Commission on the work of its forty-eighth session

- Report of the United Nations Commission on International Trade Law on the work of its twenty-ninth session

- International trade and development

- Elaboration of an International Convention to Combat Desertification in Those Countries Experiencing Serious Drought and/or Desertification, Particularly in Africa

- Special session for the purpose of an overall review and appraisal of the implementation of Agenda 21

- Convention on Biological Diversity

- Implementation of the outcome of the Global Conference on the Sustainable Development of Small Island Developing States

- Protection of global climate for present and future generations of mankind

- International Decade for Natural Disaster Reduction

Application of the Principles of the Rio Declaration on Environment and Development in International Cooperation on the Environment 132

- Institutional Arrangements for the Implementation of the Global Programme of Action for the Protection of the Marine Environment from
Land-Based Activities

132

- Convention on the law of the non-navigational uses of international watercourses

133

- Annex: Methods of work and procedures

- Establishment of an international criminal court

UN/GASS

- Programme for the Further Implementation of Agenda 21 - Extract -

- Renewing the United Nations: A Programme for Reform - Report of the Secretary General (Extract)

UNEP

- Report of the Working Group of Experts on Liability and Compensation for Environmental Damage Arising from Military Activities

- Observations and Recommendations regarding the Programme for the Development and Periodic Review of Environmental Law for the 1990 s

UNEP/GC: Decisions

- Oceans management

- Implementation of the Global Programme of Action for the Protection of the Marine Environment from Land-based Activities

- The efforts of the United Nations Environment Programme toward the implementation of the United Nations Convention to Combat Desertification in those Countries Experiencing Serious Drought and/or Desertification particularly in Africa: 1995-1996

- International action to protect human health and the environment through measures which will reduce and/or eliminate emissions and discharges of persistent organic pollutants, including the development of an international legally binding instrument

- Annex of above

- Implementation of the Programme of Action for the Sustainable Development of Small Island Developing States

- Development of an international legally binding instrument for the application of prior informed consent procedure for certain hazardous chemicals and pesticides in international trade

- Improvement of the international response to environmental emergencies

- Enhanced coherence and efficiency among international activities related to the chemicals

131 - Further measures to reduce the risks from a limited number of hazardous chemicals

- Mid-term review of the Programme for the Development and Periodic Review of Environmental Law for the 1990s and further development of international environmental law aiming at sustainable development 
- Report of the Advisory Committee on Administrative and Budgetary Questions (ACABQ) on the Environment Fund budgets: revised proposals for 1996-1997 and proposals for 1998-1999

- Management of trust funds

- Management issues and the cost of administering trust funds

- Prevention of waste, fraud and mismanagement

- The Mercure satellite communications system

- Ensuring adequate and predictable funding for the United Nations Environment Programme

- Contribution of the Governing Council of the United Nations Environment Programme to the special session of the General Assembly in 1997

- The reform of the United Nations Environment Programme

- Globalization and the environment: emerging issues on the environment and trade agenda

- United Nations system-wide strategy in the field of the environment for the period 19982002

- Coordination of convention secretariats

- Global assessment

- Biosafety
- Views expressed in the Committee of the Whole, Chairman's summary

- Governance of the United Nations Environment Programme

- Assessment of the functioning of the secretariat of the United Nations Environment Programme

UNEP - IUCN

- UNEP - IUCN - Action Plan 1997

EC

- On Environmental Agreements

- General guidelines for the use of

Environmental Agreements - (Section IV)

- Antalya Declaration Of the XI Forestry Congress Forestry for Sustainable Development: Towards the XXI Century

EU
- Draft Maastricht Treaty - Excerpts

USA

- Global ClimateChange - Remarks by US President Bill Clinton WTO

- Report of the Committee on Trade and Environment - Conclusions and

Recommendations

- Annex: For Reference - Trade and Environment - Decision of 14 April 1994

- Singapore Statement on NGO-WTO Relations

\section{ELIZABETH HAUB SPECIAL}

- Five after Rio and Fifteen Years after Montego Bay: Some Personal Reflections (T. Koh)

- The Common Concern of Mankind (A. Kiss)

- Nature of Environmental Law, in the Light of its General Theory (M. J. Magariños de Mello)

- Cluster 1 - Summaries and Discussion

- Environmental Agreements a New Instrument of Environmental Policy (E. Rehbinder)

- Les Subventions pour une Meilleure Protection de l'Environnement (H. Smets)

- Trade and Environment: Progress in the World Trade Organization? (W. Lang)

- Cluster 2 - Summaries and Discussion

- International Environmental Justice: Concept and Role (O. Kolbasov)

- Information and Participation: Required Instruments for the Improvement of Environmental Rights (P. A. Leme Machado)
- Environmental Disputes Management: A Second Look (A. O. Adede)

244 - Cluster 3 - Summaries and Discussion

- Strengthening National Compliance with International Environmental Agreements (Edith Brown Weiss)

- Compliance Control beyond Diplomacy the Role of Non-Governmental Actors (M. Bothe)

- Compliance Regimes for Multilateral Environmental Agreements - A Progress Report

- Cluster 4 - Summaries and Discussion

- HNS and Oil Pollution - Developments in the Field of Compensation for Damage to the Marine Environment (R. H. Ganten)

- Financial Guarantees for Environmental

284 Liability - Alternatives to Liability Insurance (H. Bocken)

- Cluster 5 - Summaries and Discussion

- General Debate 
Examples from Malawi

(C. O. Okidi)

- Harmonization of National Environmental Law with EU Legislation: Case of Czech Republic (Z. Madar)

- Comparative Environmental Law:

Evaluating how Legal Systems Address

"Sustainable Development"

(N. A. Robinson)

- Cluster 6 - Summaries and Discussion

- New Departures in the Legal Protection of Biological Diversity: Implementing the

Endangered Species Act (J. L. Sax)
- The Regulation and Management of Destructive Processes: A new Type of Instrument for the Conservation of Biological Diversity (C. de Klemm)

- Le Paysage en Droit Comparé et en Droit International (M. Prieur)

- Cluster - Summaries and Discussion

- The Prohibition of Hostile Military Activities in Protected Areas (W. E. Burhenne)

- Mégalopoles et Environnement 377 (J. Hoeffler)

- Cluster 8 - Summaries and Discussion

\section{AUTHORS OF SIGNED ARTICLES IN VOL. 27}

Abeyratne, R.I.R.

Adede, A.O.

Bocken, $\mathrm{H}$.

Bothe, $\mathrm{M}$.

Brown Weiss, E.

Burhenne, W. E.

Craig, D.

Ehrmann, M.

Faberon, J.-Y.

Falbo, J.A.

Ganten, R.H.

Glowka, L.

Hoeffler, J.

Jahnke, M.

Kiss, A.

de Klemm, C.

Knill, C.

Koester, V.

Koh, K. L.

Koh, T.

Kolbasov, O.

Lang, W.

Lake, R.

Loibl, G.

Lugten, G.
Leme Machado, P.A.

Madar, Z.

Manga Fombad, C.

Mann-Borgese, E.

Margariños de Mello, M.J.

Miller, D.M.

73,396

Michos-Ederer, E.A.

Oberthür, S.

192,432

Okidi, C.O.

Perez Martin, M.-T.

Posey, D.

Prieur, M.

Reiterer, M.

Rest, A.

Rehbinder, E.

Robinson, N.A.

Sax, J.L.

Schleicher, U.

Smets, H. $\quad 270$

Sutherland, J. $\quad 14$

Széll, P. $\quad 304$

Tarasofsky, R. $\quad 107$

Trüeb, H.R. $\quad 58$

Verhoosel, G. $\quad 471$ 